\title{
The effect of educational games on the emotional intelligence of the children of 13-14 ages group
}

\author{
Ali Kemal TASKIN ${ }^{1}$, Sinan AYAN ${ }^{2}$ \\ ${ }^{1}$ School of Physical Education and Sport, Yozgat University, Yozgat, Turkey. \\ ${ }^{2}$ Faculty of Sport Sciences, Kirıkale University, Kirıkkale, Turkey. \\ Address correspondence to A. K. Taşkın, e-mail; kemal_taskinn@hotmail.com
}

\begin{abstract}
In this research, the effect of educational games of children aged 13-14 on their emotional intelligences is studied. Accordingly, "Bar-on Emotional Intelligence Scale" is used to measure the emotional intelligences of children. 49 students of 8 Grade are the test group of this study. Data of the study are calculated with pre-tests and post-tests. In the comparison of pre-test and post-test values of sub-dimension of participants' emotional intelligences, it was statistically determined that there is no significant difference between the scores related to their intrapersonal skills, interpersonal skills, adaptabilities and general moods. On the contrary, in the comparison of pre-test and post-test values of subdimension of overcoming the stress, it was found that pre-test scores are significantly high. In conclusion, teachers of physical education and sports should be encouraged to be attentive to educational games and the curriculum of physical education and sports at schools should be planned according to these games. Also, researchers should be encouraged to study these games which play an important role in human development and related studies should be supported.
\end{abstract}

Keywords: Children, educational games, emotional intelligence.

\section{INTRODUCTION}

Games are as old as history of humanity. Despite many generated theories about them, their effects on human development have not been explained inclusively. Therefore, games are a field of study that is needed to be thought and studied scientifically (26). Games are developmental activities for individuals' physical, mental abilities, artistic and aesthetic qualities and skills. Games also make our life enjoyable (8). Games are entire activities that are based on voluntariness and express themselves freely, become a source of joy and contribute the development of a child, also develop senses and emotions (34). Generally, games are activities that are based on intelligence, skill, talent and vigilance, include a specific goal for child's entertainment, health and education with volunteer groups in mentally and physically restricted time and place except for daily routines, have their own rules and provide no pecuniary advantages, give pleasures and develop emotional maturity and social adaptation $(4,32)$.
The emotional interactions in the games played by children are also important for future communities' mental health. Children learn many feelings such as happiness, joy, pain, fear, anxiety, resentment, hatred, love, dependence, independence and separation in the games (2). At the same time, children reflect these reactions to the games. Children also learn to know themselves and control their emotions during the games (23). Children, who express themselves more easily during the games, are much more free and creative. For this reason, they are essential parts of educational environments (5).

Researchers have studied several times to understand the mind, find how it works and prove the superiority of it (3). The mind has been considered to be the most important element in several fields for years. It has only been used and senses have been neglected (36). The mind has always been foregrounded; therefore senses have not been considered far more important (3).

Emotions have a significant role in understanding people's thoughts and behaviors (9). According to Salovey \& Mayer (35), emotions generally consist of intrinsic or extrinsic reactions 
responded to an incident that has a positive or negative meaning for the individual. According to Frijda (15) emotions are subjective experiences. Emotion is a state of generic stimulated condition in the consciousness and the body that is created by a strong realized feeling (29). What make us different from other people are our emotions. Goleman describes emotions such properties that allow learning by mobilizing one's individual learning potential, allow to look for the unknown by asking questions, develop one's capacity and adopt a particular attitude by practicing the learned (41).

Surely, to have emotions does not merely mean anything (11). Experts conclude in the studies on human brain and nervous system that emotions are not separated from the human intelligence and they are part of it (17). The classical understanding about the brain, that is to say, the assumptions that the mind controls the emotions certainly and it is a different part of the body has been left out gradually (12). After the importance of emotions has been realized, it is also realized not only how intelligent people are but also how successful they are while getting on well with themselves and the others 19).

It is so natural that the differences between children cause disputes and conflicts in schools. The schools should focus on children's emotional life in order to avoid this type of disputes and conflicts and improve their emotional skills. Teachers and parents have important tasks to develop emotional intelligence (25). According to the experts' reports, there is a positive relationship between age, education and emotional intelligence. However, emotional intelligence also increases as people grow older and their education level increases (16). It is stated that social and environmental factors also have an impact on emotional intelligence as well as age and education (30). According to the researchers, it is told that people, who have emotional intelligence education, get healthy relationships and develop the quality of their life in affective and social domains $(27,37,42)$.

According to Coper (10) Emotional Intelligence is the ability to understand, feel and use effectively the power and rapid perception of emotions as a source of human energy, information, relationships and influence.
According to Atabek (3), Emotional Intelligence is a field of skills that develop the self and control the impulses, listen and approach empathic, solve problems and work in a group. Bar-On defines Emotional Intelligence as a set of noncognitive skills to overcome difficulties. Emotional Intelligence in Bar-On model argues that people can change their abilities and develop them with education throughout their lives. In this model, Emotional Intelligence is classified in 5 categories. These are: Intrapersonal Skills, Interpersonal Skills, Stress Management, Adaptability and General Mood (24). The aim of the recent study was to examine the effect of educational games of children aged 13-14 on their emotional intelligences.

\section{MATERIAL \& METHOD}

This research was carried out in two groups, "pre and posttest with control group and pre and posttest with experimental group". Sample group was created by randomly selected students, who were studying in 8/c and 8/d classes at Fatma Temel Turhan Secondary school in Yozgat in 2014-2015 Education year. Control group has 25 students and experimental group has 24. 24 students in experimental group were made to play educational games for 8 weeks in physical education classes, classical teaching methods were practiced to 24 students in control group. Participants' emotional intelligence subdimensions, intrapersonal and interpersonal skills, compatibility, dealing ways of stress and general moods were compared by pre-test and pro-test values in experimental and control group.

To determine the levels of students' emotional intelligence development, Bar-On EQ test, in which Reuven Bar-On studies on validity and reliability, was used. The adaption of this survey into Turkish was done by Acar (1). The original survey and translated one were compared and the phrases, which could cause misunderstanding, were revised. The survey was prepared on 5 point likert scale, and it was asked to reply; 1) Totally agree, 2) Agree, 3) Irresolute, 4) Disagree, 5) Strongly disagree. The responses to 88 th item of the survey, which were different from "Totally agree" to the phrase "I answered correctly and sincerely the above expressions" were not taken into consideration. To raise the 
reliability of the survey, internal consistency reliability analysis was used to test the reliability of the propositions in the survey. Accordingly, the Alpha coefficient was 92.12 in the survey that has 88 replies and it was an acceptable level. The basic sub-dimensions, the alpha coefficient value of intrapersonal skills was 83.73, interpersonal skills was 77.87 , adaptability was 65.42 ; stress management was 73.14 , general mood was 75.06 and they were at the acceptable level.

\section{Data Analysis}

The data in this study were collected with pre-test and post-test and the data were analyzed with the statistical program SPSS 16.0. The matched t-test was used for dependent groups and t-test was used for independent groups. The error rate was taken as 0.05 .

\section{RESULTS}

There were no statistically significant differences between the comparison of participants' sub-dimensions of emotional intelligence for experimental and control groups $(\mathrm{P}>0.05)$. Also, according to Bar-On Measuring tool, no statistically differences were found between the experimental group and control group for the students who were made to play educational games in 8 weekly physical education classes.

Table 1. The comparison of participants' sub-dimensions of emotional intelligence for experimental and control groups.

\begin{tabular}{|c|c|c|c|c|c|}
\hline Variables & Groups & Mean & SD & $\mathrm{t}$ & $\mathrm{P}$ \\
\hline \multicolumn{6}{|l|}{ Pre Test } \\
\hline \multirow[t]{2}{*}{ Intrapersonal Skills } & Experimental Group & 78.62 & 13.028 & 0.542 & 0.591 \\
\hline & Control Group & 76.96 & 8.002 & & \\
\hline \multirow[t]{2}{*}{ Interpersonal Skills } & Experimental Group & 44.54 & 12.137 & 0.222 & 0.825 \\
\hline & Control Group & 43.92 & 6.831 & & \\
\hline \multirow[t]{2}{*}{ Adaptability } & Experimental Group & 39.96 & 5.872 & -0.887 & 0.380 \\
\hline & Control Group & 41.44 & 5.824 & & \\
\hline \multirow[t]{2}{*}{ Stress management } & Experimental Group & 33.71 & 6.389 & -1.405 & 0.166 \\
\hline & Control Group & 36.08 & 5.400 & & \\
\hline \multirow[t]{2}{*}{ General mood } & Experimental Group & 31.58 & 5.429 & 0.565 & 0.575 \\
\hline & Control Group & 30.72 & 5.264 & & \\
\hline \multicolumn{6}{|l|}{ Post Test } \\
\hline \multirow[t]{2}{*}{ Intrapersonal Skills } & Experimental Group & 76.46 & 11.096 & -0.213 & 0.833 \\
\hline & Control Group & 77.28 & 15.491 & & \\
\hline \multirow[t]{2}{*}{ Interpersonal Skills } & Experimental Group & 44.79 & 7.253 & -1.239 & 0.221 \\
\hline & Control Group & 48.88 & 14.512 & & \\
\hline \multirow[t]{2}{*}{ Adaptability } & Experimental Group & 40.25 & 4.120 & 0.676 & 0.502 \\
\hline & Control Group & 39.04 & 7.775 & & \\
\hline \multirow[t]{2}{*}{ Stress management } & Experimental Group & 34.46 & 4.736 & 1.531 & 0.132 \\
\hline & Control Group & 32.44 & 4.491 & & \\
\hline \multirow[t]{2}{*}{ General mood } & Experimental Group & 29.71 & 4.369 & -0.672 & 0.505 \\
\hline & Control Group & 30.76 & 6.353 & & \\
\hline
\end{tabular}

Table 2. The comparison of the participants' sub-dimensions of emotional intelligence according to pre-test and post-test values.

\begin{tabular}{|c|c|c|c|c|c|c|c|}
\hline \multirow{2}{*}{ Variables } & & \multicolumn{3}{|c|}{ Experimental Group } & \multicolumn{3}{|c|}{ Control Group } \\
\hline & & Mean \pm SD & $\mathrm{t}$ & $\mathrm{P}$ & Mean \pm SD & $t$ & $\mathrm{P}$ \\
\hline \multirow[t]{2}{*}{ Intrapersonal Skills } & Pre-test & $78.62 \pm 13.03$ & \multirow{2}{*}{0.728} & \multirow{2}{*}{0.474} & $76.96 \pm 8.00$ & \multirow[t]{2}{*}{0.100} & \multirow[t]{2}{*}{0.921} \\
\hline & Post- test & $76.46 \pm 11.10$ & & & $77.28 \pm 15.49$ & & \\
\hline \multirow[t]{2}{*}{ Interpersonal Skills } & Pre-test & $44.54 \pm 12.14$ & \multirow{2}{*}{0.105} & \multirow{2}{*}{0.917} & $43.92 \pm 6.83$ & \multirow[t]{2}{*}{1.517} & \multirow[t]{2}{*}{0.142} \\
\hline & Post-test & $44.79 \pm 7.25$ & & & $48.88 \pm 14.51$ & & \\
\hline \multirow[t]{2}{*}{ Adaptability } & Pre-test & $39.96 \pm 5.87$ & \multirow[t]{2}{*}{0.191} & \multirow[t]{2}{*}{0.850} & $41.44 \pm 5.82$ & \multirow[t]{2}{*}{1.276} & \multirow[t]{2}{*}{0.217} \\
\hline & Post-test & $40.25 \pm 4.12$ & & & $39.04 \pm 7.78$ & & \\
\hline \multirow[t]{2}{*}{ Stress management } & Pre-test & $33.71 \pm 6.39$ & \multirow[t]{2}{*}{0.460} & \multirow[t]{2}{*}{0.650} & $36.08 \pm 5.40$ & \multirow[t]{2}{*}{2.806} & \multirow[t]{2}{*}{$0.010^{*}$} \\
\hline & Post-test & $34.46 \pm 4.74$ & & & $32.44 \pm 4.49$ & & \\
\hline \multirow[t]{2}{*}{ General mood } & Pre-test & $31.58 \pm 5.43$ & \multirow[t]{2}{*}{1.143} & \multirow[t]{2}{*}{0.265} & $30.72 \pm 5.26$ & \multirow[t]{2}{*}{0.024} & \multirow[t]{2}{*}{0.981} \\
\hline & Post-test & $29.71 \pm 4.37$ & & & $30.76 \pm 6.35$ & & \\
\hline
\end{tabular}

${ }^{*} \mathrm{P}<0.05$ 
In the comparison of the participants' subdimensions of emotional intelligence according to their pre-test and pro-test values, no significant differences were found between intrapersonal skills, interpersonal skills, adaptability, and general mood ( $P>0.05)$. On the contrary, in the comparison of participants' subdimension of stress management according to pre-test and post-test values, the pre-test values were found significantly high $(\mathrm{P}<0.05)$.

\section{DISCUSSION}

In our study it was found that, educational games for children affected five sub-dimensions of emotional intelligence; intrapersonal skills, interpersonal skills, adaptability, stress management and general mood, but this effect was not statistically significant.

It is expected that individuals with developed intrapersonal skills and interpersonal relationships should be more successful in solving problems and coping with stress. Besides, these individuals will have less adaptation problems. Away from troubles in work and daily routine, these people will have positive general mood. At the same time, we can also think that individuals with high emotional intelligence will participate in social activities a lot more. People with high interpersonal skills will not have difficulty in getting into social environments and will adapt quickly to them (30). One of the main dimensions of emotional intelligence, stress management, consists of stress tolerance and impulse control. These people can handle stress without losing their control and getting desperate (1).

Individuals with intrapersonal skills, the sub-dimensions of the emotional intelligence, can express their feelings freely. They are strong, selfconfident and independent to express their beliefs and thoughts. Therefore, it determines how peaceful they are with their inner selves, what ratio they are aware of their feelings, thoughts about themselves and what they can do in the life (38). Gündüz (21) emphasizes that games are one of the most important item in children's social and affective development.

Beceren (7) states in his study that a wellchosen game plays an important role on child's development in terms of emotional intelligence as the games are considered the most important activity of children for a long time and admitted as a unique educational experience.

Organized games in other words educational games play an important role for children to get basic skills, young people to get social communication skills by developing themselves and adults to raise their moral by having good time (13).

Besides, being enjoyable activities for children, games also affect their cognitive, emotional, social, physical and language development. Games help children to think differently, to develop their creativity, to show their joys and sorrows and to realize their feelings, to obey the moral and social rules, to enhance muscle strength and power, to develop vocabulary and expressing ability (20). The children can tell their feelings and thoughts, analyze a problem, make predictions and transfer information during the game (33).

The children's intelligence, personality and skills develop by playing games $(28,40)$. Games are the children's natural learning environments. Children try and corroborate what they see and learn during the game and improve their feelings and skills. Games are the easiest, the most direct and significant ways for children to express themselves (14). Children are free in the playground and do not recognize any restrictions (28).

In parallel with physical and mental development, children's emotional structures develop and maturate. Emotional development of the children is affected mostly by people like mother, father and teacher who are closest to them. The relationships with these people have positive and negative effects on their personality (39).

Psychological development and social development are not independent of each other. While children are learning the society, rules, occupations, customs and traditions, good and evil, right and wrong in other words they are developing socially, their identities are being shaped by what they have learned. Children should be free in the playground and solve all problems on their own. Unless it is solved, they ask their friends to help them, not anybody from outside. These behaviors are the preparations to solve the difficulties they might face when they 
grow up. If the children's behaviors are restricted and blocked by adults, they will have a blocked, timid and indecisive personality (22).

As a result, in the comparison of participants' sub-dimensions of emotional intelligence according to pre-test and post-test values, it was found that there is no statistically differences between intrapersonal skills, interpersonal skills, adaptability and general mood scores $(\mathrm{P}>0.05)$. On the contrary, in the comparison of participants' stress management methods according to pre-test and post-test values, the pre-test values were found significantly high $(\mathrm{P}<0.05)$. People with high interpersonal skills are expected to be more successful in solving problems and coping with stress. Besides, these individuals will have less adaptation problems. People with high interpersonal skills will not have difficulty in getting into social environments and will adapt quickly to these environments. Individuals with high intrapersonal skills, the sub-dimensions of the emotional intelligence, can express their feelings and thoughts easily. Not only children find a chance to know themselves by revealing their emotional skills, but also they gain the ability of control themselves. Besides, games are enjoyable activities for children; they also affect their cognitive, emotional, social, physical and language development.

Games help children to think differently, develop their creativity, express their joy, sadness and realize their emotions, obey social and moral rules by socializing in groups of friends, enhance muscle strength and power, and develop vocabulary and expression skills. During the game, the children have activities such as expressing their emotions and thoughts, analyzing a problem, making a prediction and transferring information.

To build a proper emotional structure of an individual has an important role in every aspect of life, particularly in adolescence. Owing to the fact that people with high emotional intelligence build the society on a solid basis, activities such as educational games that affect the development of emotional intelligence positively are frequently put into practice in the education, school and social life of young people (4).

\section{REFERENCES}

1. Acar FT. Duygusal zekâ yeteneklerinin göre ve yönelik ve insana yönelik liderlik davranışları ile ilişkisi. Yayımlanmamış doktora tezi, İstanbul Üniversitesi, 2001.

2. Akandere M. Eğitici Okul Oyunları, 1. Basım, Ankara: Nobel Yayın Dağıtım, 2003.

3. Atabek E. Bizim duygusal zekamız, 2. Basım, İstanbul: Altın Kitaplar Yayınevi, S. 21, 2000.

4. Ayan S. İlköğretim I. ve II. kademede beden eğitimi dersinin amaçlarina göre uygulanma durumunun incelenmesi. Doktora Tezi, Gazi Üniversitesi Eğitim Bilimleri Enstitüsü Beden Eğitimi ve Spor Öğretmenliği Anabilim Dalı, Ankara, 2007.

5. Ayan S, Dündar H. Eğitimde okul öncesi yaraticiliğin ve oyunun önemi. Ahmet Keleşoğlu Eğitim Fakültesi Dergisi, 2009; 28: 63-74.

6. Bar-On R. EQ-I: The Emotional Quotient Inventory Manual. A Test of Emotional Intelligence, New York: Multi-Health Systems, 1995.

7. Beceren E. Çocuklarda Duygusal Zeka Gelişimi. Personal Excellence. icsayfa.aspx?Sid=83\&Tid=18, 2002.

8. Bilen M. Plandan Uygulamaya. Ankara: Anı Yayıncılık, 2002: 203.

9. Champoux JE. Organizational Behaviour: Integrating Individuals, Groups and Organizations. USA: Thomson South Western. 2006: 108.

10. Cooper RK. Appliying emotional inteligence in the workplace. Traning and Development, 1997; 51(12): 31-38.

11. Cooper RK, Sawaf A. Liderlikte duygusal zeka. İstanbul: Sistem Yayıncılık, 2000.

12. Çakar U, Arbak Y. Modern yaklaşımlar 1şı̆̆ında değişen duygu-zekâ ilişkisi ve duygusal zekâ. Dokuz Eylül Üniversitesi Sosyal Bilimler Enstitüsü Dergisi, 2004; 6(3): 23-48.

13. Çamlıyer H. Eğitim Bütünlüğü İçinde Çocuk Hareket Eğitimi ve Oyun. Manisa: Celal Bayar Üniversitesi Matbaası, 2009.

14. Çoban B, Nacar E. Okul Öncesi Eğitimde Eğitsel Oyunlar. Ankara: Nobel Yayın Dağıtım, 2006.

15. Frijda NH. The laws of emotion. American Psychological Association, 1988; 43(5): 349-358.

16. Ergin DY, İşmen E, Özabacı N. EQ-NED Duygusal zekâ Ölçeği El Kitabı. İstanbul, 2000.

17. Epstein JH. Computers with emotions. The Futurist, 1998; 32(3): 4-5.

18. Gardner L, Stough C. Examining the relationship between leadership and emotional intelligence in senior level managers. Leadership and Organization Development Journal, 2002; 23(2): 68-78.

19. Goleman D, Boyatzis R, McKee A. The emotional reality of teams. Journal of Organizational Excellence, 2002; (21(2): 55-65. 
20. Gülsoy T, Uçgun D. 6. Sınıf Öğrencilerinin Kelime Hazinesinin Geliştirilmesinde Eğitsel Oyunların Etkisinin İncelenmesi, Niğ̉de Üniversitesi, Eğitim Fakültesi, 2013.

21. Gündüz Y. Çocuğunuzun Başarısı Elinizdedir. İzmir: Tibyan Yayıncilık İzmir, 2001.

22. Hazar M. Beden Eğitimi ve Sporda Oyunla Eğitimi Ankara, 1996.

23. Huizinga J. Homo Ludens. Oyunun Toplumsal İşlevi Üzerine Bir Deneme (Çev: M. A. Kılıçbay). İstanbul: Ayrıntı Yayınları, 1995.

24. Köksal A. Bar-On Duygusal Zeka Ölçeği Çocuk ve Ergen Formu geçerlik güvenirlik çalışması. Uluslararası Duygusal Zeka Sempozyumu, İzmir, 2007: 498- 509.

25. Kansu N. Okullarda duygusal zeka. Personal Excellerce, 2002; 6(8): 13-16.

26. Koçyiğit S, Tuğluk M, Kök M. Çocuğun gelişim sürecinde eğitsel bir etkinlik olarak oyun. Kazım Karabekir Eğitim Fakültesi Dergisi, 2007: (16).

27. Mayer JD, Salovey P. What is Emotional Intelligence? Emotional Development and Emotional Intelligence. New York: BasicBooks, 1997.

28. Memiş DA. Oyunun çocuk gelişimine etkisi ve eğitimdeki önemi. Ulusal Sınıf Öğretmenliği Kongresi, 14-16 Nisan, GaziÜniversitesi, Ankara: Kök Yayıncllık, II, 442-448, 2006

29. Nyland B. Listening to infants: emotional literacy and the child care setting. International Journal of Early Childhood, 1999; 31(2): 99-104.

30. Öztürk A, Deniz ME. Okul öncesi öğretmenlerin duygusal zekaye tenekleri, iş doyumları ve tükenmişlik düzeylerinin bazı değişkenler açısından incelenmesi. İlköğretim-Online, 2008; 7(3): 578-599.

31. http://www.ilkogretim-online.org.tr, Erişim tarihi: 04.03.2013.

32. Onay C. Çoklu zeka kavramına göre oyunla eğitim. Ankara: Nobel Yayın Dağıtım, 2006.

33. Pehlivan H. Oyun ve Öğrenme. Ankara: Anı Yayıncılık, 2005.

34. Razon N. Okul öncesi eğitimde oyunun, oyunda yetişkinin işlevi. İstanbul Okul Öncesi Eğitimi ve Yaygınlaştırılması Semineri Dergisi, 1985; II-III: 57.

35. Salovey P, Mayer JD. Emotional intelligence. Imagination, Cognition and Personality, 1989-1999; 9(3): 185-211.

36. Sartorius M. Kadınlarda duygusal zeka. Çev: S. C. Erendor. İstanbul: Varlık Yayınları, 1999.

37. Shapiro LE. Yüksek EQ’lu Bir Çocuk Yetiştirmek. Çev: Ü. Kartal, İstanbul: Varlık Yaınları, 1998.

38. Stein JS, Book HE. EQ Duygusal Zekâ ve Başarının Sırrı. İstanbul: Özgür Yayınları, 2003.

39. Tuncor F. Eğitici Çocuk Oyunları. İstanbul: Esin Yayınları, 2000.

40. Yamaner F. Beden Eğitimi ve Sporda Temel İlkeler. Bursa: Ekin Kitabevi, 2001.

41. Yelkikalan N. 21. Yüzyılda girişimcinin yeni özelliği: duygusal zeka. Çanakkale Onsekiz Mart Üniversitesi Girişimcilik ve Kalkınma Dergisi, 2006; 1: 39-50.

42. Weisinger H. İş Yaşamında Duygusal Zeka. Çev: N. Süleymangil, İstanbul: MNS Yayıncllık, 1998. 